DOI https://doi.org/10.18551/rjoas.2017-12.13

\title{
THE INFLUENCE OF INFORMATION SYSTEM QUALITY ON THE ORGANIZATION PERFORMANCE: A MODIFICATION OF TECHNOLOGY-BASED INFORMATION SYSTEM ACCEPTANCE AND SUCCESS MODEL
}

\author{
Trisnawati Novi ${ }^{*}$, Baridwan Zaki, Hariadi Bambang \\ Faculty of Economics and Business, University of Brawijaya, Indonesia \\ *E-mail: novitrisnawati.nt@gmail.com
}

\begin{abstract}
This study aims to examine the effect of information system quality on technology-based accounting information systems usage and their impact on organizational performance on local government. This study is based on Technology Acceptance Model (TAM), IS Success Model, and the success of technology-based information systems. This study is a combination of previous studies conducted by Seddon and Kiew (1997), Saeed and Helm (2008), and DeLone and McLean (1992). This study used survey method and took 101 respondents from accounting staff working in Malang and Mojokerto regencies. This study uses Partial Least Square to examine research data. Research result exhibits information system qualities affecting benefit perception and user satisfaction. Technology-based accounting information systems usage in local government is influenced by benefits perception and user satisfaction. Research result concluded that technology-based accounting information systems usage will affect the performance of local government organizations.
\end{abstract}

\section{KEY WORDS}

Organization performance, system usage, Technology Acceptance Model, IS Success Model.

Technology is growing rapidly, especially in information and communication fields. This development is also seen in accounting field exhibited in the emergence of technology based accounting information system (AIS).

This study raises the behavioral issue of technology-based accounting information systems usage in local governments. A technology-based Accounting Information System aids accounting staff at local government in the process of developing Local Government Financial Statements. The accounting staff in charge inputs organization transaction data which then would be processed by the application, therefore produce output in the form of financial statements. The information in these financial statements can be used by top managers in a decision-making process.

Technology-based accounting information system will certainly affect the workforce in accounting field. The use of AIS applications is expected to improve the performance of the accounting field which would indirectly improve the overall organization performance. However, according to Usnodo (2010), about $70 \%$ of information systems failed to be applied due to behavioral aspects issue.

This study uses 3 models as the basis of its research, namely TAM (Davis et al, 1989), IS Success Model (DeLone and McLean, 1992), as well as technology-based information systems acceptance and success model (Baridwan, 2012).

Building a technology-based accounting information system requires huge investment. Mistakes in choosing or applying AIS applications will cause a material loss especially to a government organization (local government). Therefore, identifying the determinants on acceptance of information technology becomes essential to develop information system therefore high investment in IT facilities becomes useful and valuable for the organization. To avoid losses due to AIS application failure, local governments need tools to evaluate their success. 
This study is an amalgamation of three previous studies by DeLone and McLean (1992); Seddon and Kiew (1997); and Saeed and Helm (2008). The first study was DeLone and McLean research (1992) on the success model of technology-based information systems. The second study was Seddon and Kiew research (1997) that reviewed the DeLone and McLean information systems success model. This study examines the relationship between five variables, system quality, information quality, usefulness, user satisfaction, and importance of the system. A third study by Saeed and Helm (2008) examined the effect of information system characteristics and beneficiary perceptions on the use of post-adoption information systems. Based on these three studies, there are five variables tested in this study, namely information system qualities, benefit perception, user satisfaction, system usage, and organizational performance.

In the previous research models DeLone and McLean's success of information systems model were widely used to examine private companies. On the other hand, this study examined public sector organizations in East Java Province.

\section{LITERATURE REVIEW}

Technology based accounting information system. The accounting information system (AIS) is a system that collects, records, stores, and processes data into useful information in assisting decision-making processes (Romney and Steinbart, 2012: 30). AIS helps managers to gain information which is used as a basis for organization's strategic decision-making process. Technology-based AIS can help organizations to improve their performance.

Technology Acceptance Model (TAM) is model used to analyze and understand the factors affecting acceptance of computer technology usage which was developed by Davis et al (1989). The TAM model, developed based on psychological theory, describes computer user behavior based on belief, attitude, intention, and user behavior relationship. The purpose of this model is to explain the main factors of user behavior on technology users acceptance.

The DeLone and McLean Information Systems Success Model (IS Success Model). This model was developed by DeLone and McLean in 1992 based on a causal relationship process of six dimensions consisting of system quality, information quality, usage, user satisfaction, individual impact and organizational impact. The IS Success Model does not independently measure these dimensions but measures them as a whole. This model is a parsimony model, therefore, this model is useful to test and analyze the success of information systems in organizations that applied information technology.

Technology-Based Information System Acceptance and Success Model. This model is the result of Baridwan's study (2012). This model is a combination of Unified Theory of Acceptance and Use Of Technology (UTAUT), and Information System Success Model. There are eight constructs in this model: performance expectations, business expectations, social influences, facilitating conditions, age, interest in behavior, user behavior, and organizational performance. Age is a moderating variable in social influence on individual behavior interests using technology-based accounting information system. This model explains that the implementation of technology-based accounting information systems received by individuals will be successful and have a positive impact on organizational performance if the system is easy to operate, existing social influences, and the existence of adequate supporting facilities.

Research Method and Hypothesis. Information system quality describes desired quality of an information system (DeLone and McLean in Livari 2005). The information system quality construct is defined by the IS Success Model developed by Delone and McLean (1992). Furthermore, DeLone and McLean information system success model was improved by Seddon and Kiew in 1997 by connecting system quality and information quality variable on benefit perception. Several other studies (Kim \& Lee, 2014, Ali \& Younes, 2013, HsuehYing Wu et al, 2010, Saeed \& Helm, 2008) also stated that there is a positive relationship between information system qualities and benefit perception.

$H_{1}$ : Information system qualities positively affects the perception of benefits. 
In addition to benefit perception, user satisfaction is an important factor in the application of technology-based information systems. Based on DeLone and McLean is success model, there is a relationship between information system qualities with user satisfaction. In several studies such as DeLone and McLean (1992), Seddon and Kiew (1997), Choga et al (2014), Kim and Lee (2014), Peter et al. (2008), DeLone and McLean (2003) discussed the relationship between information system qualities and user satisfaction.

$\mathrm{H}_{2}$ : Information system qualities has a positive effect on user satisfaction.

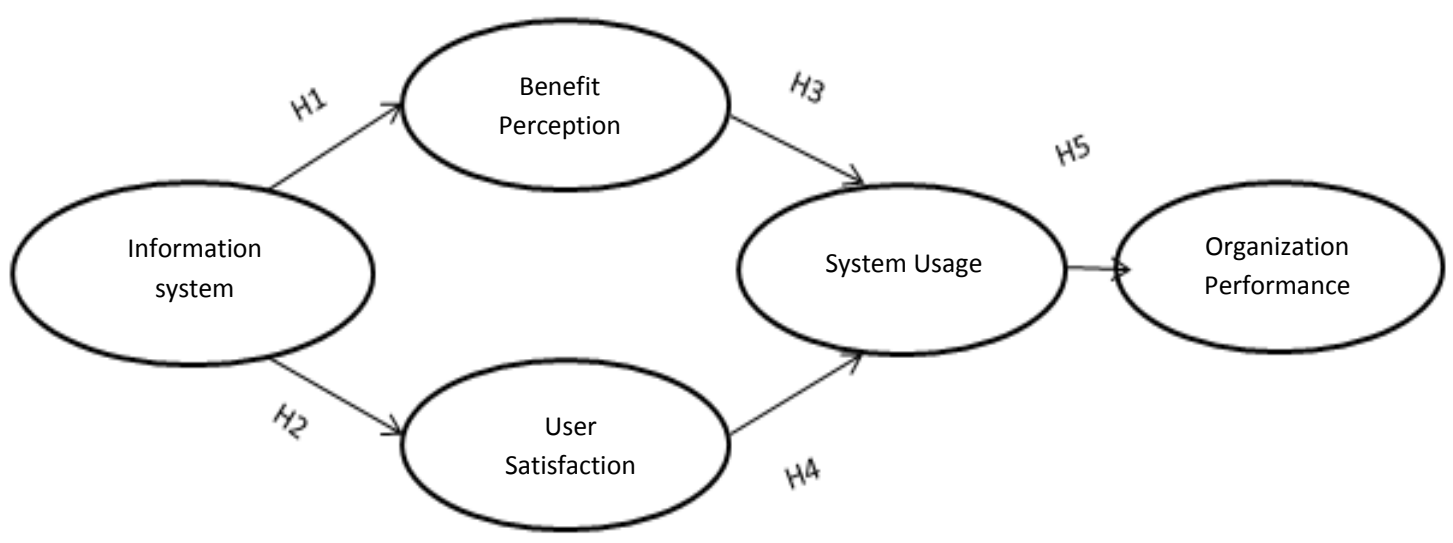

Figure 1 - Research Model

Benefit Perception is the level of user trust using a particular system which improves its performance (Davis 1989). Davis' research (1989) has predicted that benefit perception as the most powerful predictive variable in information system usages. Several other studies (Adams et al, 1992, Kim \& Lee, 2014, Saeed \& Helm, 2008; Venkatesh et al., 2003; Masseti \& Zmud, 1996) also suggest that there is a positive relationship between benefit perception and the system usage.

$\mathrm{H}_{3}$ : Benefit perception positively affects information system usages.

User satisfaction is defined as user confidence level in information system used to be able to meet the need for information (Baroudi, 1983). In previous researches, end user satisfaction and system usage are often used as key variables in evaluating information systems success rate (Iqbaria and Tan 1997). Several other studies (DeLone \& McLean, 1992; Igbaria \& Tan, 1997; Bokhari, 2005; Kim \& Lee, 2014; Peter et al. 2008; livary; 2005; Hollsaple \& Lee-post, 2006) suggest that there is a positive relationship between user satisfaction and system usage.

$\mathrm{H}_{4}$ : User satisfaction positively affects information system usage.

System usage is one of the key variables in most theoretical frameworks in the information technology research literature. The system usage reflects the success of system application itself. The system usage will have an impact on the organization. Organizational impact or other terms of organizational performance is the result of the behavioral use of technology-based AIS by individuals within the organization (DeLone and McLean, 1992 and 2003). Wang and Liao's research (2008) provide empirical evidence based on their research that the use of technology-based systems affects organization performance. Another study supporting this statement is Baridwan (2012), D \& M (1992), Roldan and Leal (2003), Peter and McLean (2009), Hollsaple and Lee-Post (2006), Urbach et al. (2010), DeLone and McLean's research (2003).

$H_{5}$ : Information system usages has a positive effect on organization performance.

\section{METHODS OF RESEARCH}

Sample. The sample used in this study were 159 accounting staffs working in Malang and Mojokerto, Indonesia. The researcher submitted the research questionnaire by direct survey method and by mail. Data collection was conducted from September to October 2017. 
Procedure. Sampling method used is convenience sampling. Convenience sampling method is a sampling technique where researchers freely select sample (Hartono, 2015: 98). The reason for selecting convenience sampling method is to facilitate sampling conducted by the researcher. Researcher collect sample data by proportional division for 3 respondents at each SKPD.

Measurement and research instruments. The indicators and question items of quality system information constructs are taken from Livari (2005) and Baridwan research (2012) as much as 7 items. The construct of perceived benefit perception was 4 from Venkatesh et al (2000) and Davis et al. research (1989). The user satisfaction construct consists of 4 indicators taken from Weber's research (1999) and the questionnaire used was adopted from Doll and Torkzadeh research (1988). The system usage consists of 3 indicators was taken from Livari (2005), Baridwan (2012), Seddon and Kiew research (1997). The perceived organizational performance consists of 3 indicators taken from Roldan and Leal (2003), and Baridwan's research (2012). Each indicator is measured by drawing a Likert scale of 1 (one) to 7 (seven). 1 = strongly disagree, 2 = disagree, $3=$ somewhat disagree, $4=$ neutral, $5=$ somewhat agree, $6=$ agree, $7=$ strongly agree .

\section{RESULTS OF STUDY}

Based on survey results, the majority of respondents are male (54\%) with an average age of 20 to 30 years (50\%). Most respondents work experience was more than 3 years $(51 \%)$ and experience using technology-based system between $2-5$ years $(48 \%)$.

The loading factor value of all constructs is greater than 0.7 and the value of AVE and communality is more than 0.5 . Therefore it can be concluded that the constructs and indicators in this study have met the convergence validity test. Table 2 exhibits that construct possessing higher AVE root value than the latent variable correlation value means that all constructs have met the discriminant validity test. All constructs have also met the reliability test with a value of Cronbach's alpha over 0.6 and a composite reliability value greater than 0.7 .

Table 1 - Factor and Model Assessment Analysis Result

\begin{tabular}{|c|c|c|c|c|c|c|c|}
\hline Construct & Item & $\begin{array}{l}\text { Original } \\
\text { Sample }\end{array}$ & $\begin{array}{c}\mathrm{T} \\
\text { Statistic }\end{array}$ & AVE & Communality & $\begin{array}{c}\text { Cronbach } \\
\text { Alpha }\end{array}$ & $\begin{array}{l}\text { Composite } \\
\text { Reliability }\end{array}$ \\
\hline \multirow{7}{*}{$\begin{array}{l}\text { Information System } \\
\text { Quality (ISQ) }\end{array}$} & ISQ1 & 0,7968 & 32,6397 & \multirow{7}{*}{0,6437} & \multirow{7}{*}{0,6437} & \multirow{7}{*}{0,9086} & \multirow{7}{*}{0,9266} \\
\hline & ISQ2 & 0,8343 & 45,5244 & & & & \\
\hline & ISQ3 & 0,8162 & 44,9584 & & & & \\
\hline & ISQ4 & 0,8495 & 52,8033 & & & & \\
\hline & ISQ5 & 0,7596 & 27,7248 & & & & \\
\hline & ISQ6 & 0,7908 & 52,6298 & & & & \\
\hline & ISQ7 & 0,7646 & 41,1024 & & & & \\
\hline \multirow{4}{*}{$\begin{array}{l}\text { Benefit Perception } \\
\text { (BP) }\end{array}$} & BP1 & 0,8697 & 72,9044 & \multirow{4}{*}{0,6723} & \multirow{4}{*}{0,6723} & \multirow{4}{*}{0,8356} & \multirow{4}{*}{0,8908} \\
\hline & BP2 & 0,8864 & 84,6973 & & & & \\
\hline & BP3 & 0,7828 & 43,1055 & & & & \\
\hline & BP4 & 0,7308 & 27,6047 & & & & \\
\hline \multirow{4}{*}{$\begin{array}{l}\text { User Satisfaction } \\
\text { (US) }\end{array}$} & US1 & 0,9451 & 112,4563 & \multirow{4}{*}{0,7672} & \multirow{4}{*}{0,7672} & \multirow{4}{*}{0,8972} & \multirow{4}{*}{0,9289} \\
\hline & US2 & 0,9592 & 171,695 & & & & \\
\hline & US3 & 0,8079 & 19,1746 & & & & \\
\hline & US4 & 0,7766 & 44,1639 & & & & \\
\hline \multirow{3}{*}{ System Usage (SU) } & SU1 & 0,8888 & 87,9882 & \multirow{3}{*}{0,7444} & \multirow{3}{*}{0,7444} & \multirow{3}{*}{0,8295} & \multirow{3}{*}{0,8971} \\
\hline & SU2 & 0,8057 & 35,985 & & & & \\
\hline & SU3 & 0,8911 & 61,0369 & & & & \\
\hline \multirow{3}{*}{$\begin{array}{l}\text { Organization } \\
\text { Performance (OP) }\end{array}$} & OP1 & 0,915 & 102,5189 & \multirow{3}{*}{0,7543} & \multirow{3}{*}{0,7543} & \multirow{3}{*}{0,8352} & \multirow{3}{*}{0,9017} \\
\hline & OP2 & 0,8985 & 71,4178 & & & & \\
\hline & OP3 & 0,7864 & 30,8663 & & & & \\
\hline
\end{tabular}

The hypothesis could be accepted should sample original value or beta $(\beta)$ is positive and its t-statistic is greater than 1.64. Hypothesis 1 was accepted since there is a positive correlation between information system quality with benefit perception with beta value $(\beta)$ is 
positive equal to 0,4076 and T-statistic value equal to 7,5923. Hypothesis 2 which states there is a positive relationship between information system qualities with user satisfaction is accepted with positive beta value $(\beta)$ at 0,3849 and the value of T-statistic is 9,3957 . Hypothesis 3 which states there is a positive relationship between benefit perception and system usage is also accepted with the positive beta value $(\beta)$ at 0,4593 and T-statistic value of 10,2251 . Hypothesis 4 is also accepted with positive beta value $(\beta)$ equal to 0,2198 and value of T-statistic equal to 4,6635 which indicates existing positive relationship between user satisfaction and system usage. Hypothesis 5 was accepted with positive beta value $(\beta)$ equal to 0,4968 and value of T-statistic perception benefit construct to system usage equal to 14,906 .

Table 2 - AVE Root and correlation of latent variables

\begin{tabular}{|c|c|c|c|c|c|c|c|}
\hline & struct & Akar AVE & 1 & 2 & 3 & 4 & 5 \\
\hline 1 & Information System Quality & 0,8023 & 1 & 0 & 0 & 0 & 0 \\
\hline 2 & Benefit Perception & 0,8199 & 0,4076 & 1 & 0 & 0 & 0 \\
\hline 3 & User Satisfaction & 0,8759 & 0,3849 & 0,5935 & 1 & 0 & 0 \\
\hline 4 & System Usage & 0,8628 & 0,504 & 0,5898 & 0,4925 & 1 & 0 \\
\hline 5 & Organization Performance & 0,8685 & 0,4118 & 0,5809 & 0,8749 & 0,4968 & 1 \\
\hline
\end{tabular}

Table 3 - Hypothesis Examination Result

\begin{tabular}{clrrr}
\hline Hypothesis & Construct & Original Sample & T Statistics & Decision \\
\hline H1 & Information System Quality - > Benefit Perception & 0,4076 & 7,5923 & Accepted \\
H2 & Information System Quality -> User Satisfaction & 0,3849 & 9,3957 & Accepted \\
H3 & Benefit Perception -> System Usage & 0,4593 & 10,2251 & Accepted \\
H4 & User Satisfaction -> System Usage & 0,2198 & 4,6635 & Accepted \\
H5 & System Usage -> Organization Performance & 0,4968 & 14,906 & Accepted \\
\hline
\end{tabular}

\section{DISCUSSION OF RESULTS}

This study examines the effect of information system quality on technology-based accounting information systems usage and their impact on the performance of local government organizations. Based on hypothesis assessment result, every hypothesis in this research was accepted. This research adopted three previous models: TAM (Davis et al, 1989), IS Success Model (DeLone and McLean, 1992), and Technology-Based Information System Acceptance and Success Model (Baridwan, 2012).

The first hypothesis in this study states that information system qualities positively affect benefit perception in using technology-based accounting information systems. These results indicate that the better information system qualities in technology-based accounting information systems is considered more useful for its users. This study supports previous studies conducted by Seddon and Kiew (1997), Kim and Lee (2014), Ali and Younes (2013), Saeed and Helm (2008) and Hsueh-Ying Wu, et al. (2010). The results of this study state that information system qualities have a positive effect on user satisfaction. This study supports previous studies by Livari (2005), Hollsaple and Lee-Post (2006), Kim and Lee (2014), Choga and Nyaruwata (2014) and Peter et al. (2008). The results of this study support previous studies conducted by Adams et al. (1992) using TAM basic theories. Adams et al research (1992) stated that there is a positive relationship between benefit perception and system usage. Other studies that also support this study are Saeed and Helm (2008), Kim \& Lee (2014), Davis (1989), Venkatesh et al. (2003), and Massetti \& Zmud researchs(1996).

Research result concluded that user satisfaction has a positive effect on system usage. These results are supported by previous studies conducted by Igbaria and Tan (1997), Bokhari (2005), DeLone and McLean (1992), Kim and Lee (2014), Peter et al. (2008), livary (2005), Hollsaple and Lee-post (2006). The results of this study also state that there is a positive relationship between the use of system with organizational performance. These results support the results of previous research conducted by Petter and McLean (2009), 
Lee-Post (2009), Urbach et al. (2010), DeLone and McLean (2003), Wang and Liao (2008) and Baridwan (2012).

Implications of research. This study has two implications, namely theoretical implications and practical implications. The theoretical implications of this research that this research result can support the theory used which are TAM, IS Success Model, and the Technology-Based Information System Acceptance and Success Models (Baridwan, 2012). The practical implications indicates that this study can be used as a reference in planning and development of technology-based information systems on local government related to behavioral aspect.

\section{CONCLUSION}

This study aims to examine the effect of information system quality on technologybased accounting information systems usage and their impact on organizational performance on local government. The survey process was conducted in two ways, by giving directly to the respondents through hardcopy and send letters by mail to respondents whose location could not be reached by the researcher. Total respondents in this study were 101 respondents.

This study used three models as the basis of its research, TAM (Davis et al 1989), IS Success Model (DeLone and McLean, 1992), and a technology-based information systems acceptance and success model (Baridwan, 2012). The results of this study support these three models.

Research result indicate that information system qualities affect benefit perception and user satisfaction positively in using technology-based accounting information systems in local government. Technology-based accounting information systems usage in local government is influenced by benefit perception and user satisfaction on the system itself. High usage level in using accounting software will increase the intensity of actual system usage. If the user is satisfied while using a technology-based AIS, it would increase the system usage. It could be concluded that the technology based accounting information system usage has a positive effect on the performance of local government organizations.

\section{REFERENCES}

1. Abdillah, Willy dan Jogiyanto Hartono. 2015. Partial Least Square (PLS): Alternative Structural Equation Modeling (SEM) dalam Penelitian Bisnis. C.V. Andi Offset. Yogyakarta.

2. Adams, Dennis A., R. Ryan Nelson, dan Peter A Todd. 1992. Perceived Usefulness, Ease of Use, and Usage of Information Technology A Replication." MIS Quarterly Journal.

3. Ali, Bejjar Mohamed dan Younes Boujelbene. 2013. The impact of information systems on user performance: an exploratory study. Journal of Knowledge Management, Economics and Information Technology, Issue2, April.

4. Baridwan, Zaki. 2012. Analisis Keperilakuan Individu Terhadap Implementasi Sistem Informasi Akuntansi: Model Penerimaan Dan Kesuksesan Sistem Informasi Berbasis Teknologi. Disertasi. Program Doktor IImu Akuntansi, Program Pascasarjana Fakultas Ekonomi dan Bisnis, Universitas Brawijaya.

5. Baroudi, Jack J., M.H., Margrethe H. Olson, dan Blake Ives. 1986. An Empirical Study of the Impact of User Involvement on System Usage and Information Satisfaction. Communication of the ACM 29: 232-238

6. Bokhari, Rahat H. 2005. The Relationship Between System Usage and Kepuasan pengguna akhir: a Meta Analisys. Journal of Enterprise Information Management 18, Issl/2: 221.

7. Choga, Farai dan Nyaruwata, Leonorah Tendai. 2014. The Role of Information Quality as a Determinant of Production System Usage, User Satisfaction and Companies Benefits: The Application of DeLone and McLean Information System Success Model in the 
Zimbabwean Manufacturing Sector. International Journal of Innovative Research in Management.

8. Davis, Fred D. 1989. Perceived Usefulness, Perceived Ease of Use, and User Acceptance of Information Technology. MIS Quarterly September: 319- 340.

9. Davis, Fred D., Richard P. Bagozzi, dan Paul R. Warshaw. 1989. User Acceptance of Computer Technology: A Comparison Two Theoretical Models. Management Science 35, no. 8: $982-1003$.

10. DeLone, William H. 1988. Determinants of Success for Computer Usage in Small Business. MIS Quarterly March: 51-61

11. DeLone, William H. dan Ephraim R. Mclean. 1992. Information System Success: The Quest for the Dependent Variable. Information System Research March: 60-95.

12. DeLone, William H. dan Ephraim R. Mclean. 2003. The DeLone and McLean Model of Information Systems Success: A Ten-Year Update. Journal of Management Information Systems (19:4), 9-30.

13. Doll, William J. dan Gholamreza Torkzadeh. 1988. The Measurement of End User Computing Satisfaction. MIS Quarterly 12, no.2: 159-174.

14. Ghozali, Imam. dan Hengky Latan. 2015. Konsep, Teknik, Aplikasi Menggunakan Smart PLS 3.0 Untuk Penelitian Empiris. BP Undip. Semarang.

15. Hartono, Jogiyanto. 2007. Model Kesuksesan Sistem Teknologi Informasi. BPFE. Yogyakarta.

16. Hartono, Jogiyanto. 2015. Metodologi Penelitian Bisnis:Salah Kaprak dan PengalamanPengalaman. C.V. Andi Offset. Yogyakarta.

17. Holsapple, Clyde W. dan Anita Lee-Post. 2006. Defining, Assessing, and Promoting ELearning Success: An Information Systems Perspective. Decision Sciences Journal of Innovative Education.

18. Igbaria, M. and M. Tan. 1997. The Consequences Of Information Technology Acceptance On Subsequent Individual Performance. Elsevier Science Publisher. Amsterdam.

19. Kim, Yoojung., dan Hyung Seok Lee. 2014. Quality, Perceived Usefulness, User Satisfaction, and Intention to Use: An Empirical Study of Ubiqitous Personal Robot Service. AOFn Social Science 10, no. 11: 1-16.

20. Livari, Juhani. 2005. An Empirical Test of the DeLone and McLean Model of Information System Success. Database for Advances in Information Systems Spring 36, no. 2: 8.

21. Massetti, Brenda dan Zmud, Robert W. 1996. Measuring the Extent $f$ EDI Usage in Complex Organizations: Strategies and Illustrative Examples. MIS Quarterly Vol 20 No 3.

22. Petter, Stacie. William DeLone dan Ephraim McLean. 2008. Measuring information systems success: models, dimensions, measures, and interrelationships. European Journal of Information Systems 17, 236-263.

23. Roldan, Jose L., dan Antonio Leal. 2003. A Validation Test of An Adaptation of The DeLone and McLean's Model in Spanish EIS Field. Idea Group Publishing.

24. Romney, Marshall B. dan Paul John Steinbart. 2015. Sistem Informasi Akuntansi. Salemba Empat. Jakarta.

25. Saeed, Khawaja A \& Sue Abdinnour Helm. 2008. Examining The Effects of Information System Characteristics and Perceived Usefulness On Past Adaption Usage of Information Systems. Information \& Management. Vol. 45, pp: 376-386.

26. Seddon, Peter B. 1997. "A Respecification and Extension of The DeLone and McLean's Model of IS Success." Information System Research 8: 240-250.

27. Seddon, Peter B. dan Min-yen Kiew. 1997. A Partial Test and Development of DeLone and McLean's Model of IS Success. AJIS.

28. Sekaran, Uma dan Roger Bougie. 2013. Research Methods for Business. Jhon Wiley \& Sons Ltd. United Kingdom.

29. Sholihin, Mahfud dan Dwi Ratmono. 2013. Analisis SEM-PLS dengan WrapPLS 3.0 Untuk Hubungan Nonlinear dalam Penelitian Sosial dan Bisnis. C.V. Andi Offset. Yogyakarta. 
30. Urbach, N., Smolnik, S. dan Riempp, G. 2010. An empirical investigation of employee portal success. Journal of Strategic Information Systems 19, 184206.

31. Usnodo, Isno. 2010. Lead Business with IT (Seri korporasi Warta Ekonomi E-Company Award 2009). edited by H. Adrian. Dian Rakyat. Jakarta.

32. Venkatesh, Viswanath., Michael G. Morris., Gordon B. Davis dan Fred D. Davis. 2003. User Acceptance of Information Technology:Toward a Unified View. MIS Quarterly, 27(3).

33. Wang, Yi-Shun. 2002. The Adoption of Electronic Tax Filing Systems: An Empirical Study. Government Information Quarterly, 20, 333-352.

34. Weber, Ron. 1999. Information System Control and Audit. Prentice Hall, Inc. New Jersey.

35. Wu, Hsueh-Ying., Chun-Chun Line, Cheng-Lung Li dan Hsing-Hui Lin. 2010. A Study Of Bank Customers' Perceived Usefulness Of Adopting Online Banking. Global Journal of Business Researc, . Volume 4.

36. Yoojung Kim dan yung Seok Lee. 2014. Quality, Perceived Usefulness, User Satisfaction, and Intention to Use: An Empirical Study of Ubiquitous Personal Robot Service. Asian Social Science; Vol. 10, No. 11; 2014.

37. Zviran, Moshe., Nava Pliskin dan Ron Levin. 2005. Measuring User Satisfaction and Perceived Usefulness in the ERP Context. Journal of Computer Information Systems, 45:3, 43-52. 